\title{
Improving cell adhesion on titanium by covalent immobilization of collagen
}

\section{Erhöhung der Zelladhäsion auf Titan durch kovalente Anbindung von Kollagen}

Autoren: Rainer Müller ${ }^{1}$, Jochen Abke ${ }^{1}$, Richard Kujat ${ }^{2}$ and Peter Angele ${ }^{2}$

Dedicated to the $65^{\text {th }}$ birthday of Prof. Dr. Hartmut Worch

Schlagworte: Zelladhäsion, Titan, Kollagen, kovalente Immobilisierung

Keywords: cell adhesion, titanium, collagen, covalent immobilization

Zitierweise dieses Beitrages: BI0materialien 2007; 8 (1): S. 40-45
Die initiale Adhäsion von Körperzellen ist eine wesentliche Voraussetzung für die erfolgreiche Integration eines Implantatwerkstoffs in das zu regenerierende Gewebe. Die Verbesserung der Oberflächeneigenschaften von Implantaten kann zu einer schnelleren Einheilung des Werkstoffs führen und damit zu einer Reduktion von Komplikationen wie z.B. Infektionen oder Pseudoarthrosen beitragen. Neben der gezielten Veränderung der Oberflächentopografie ist die Modifizierung von Biomaterialoberflächen mit bioaktiven Verbindungen ein erfolgversprechender Ansatz zur Beeinflussung der Reaktion zwischen Zelle und Werkstoff. Dabei hat sich besonders die Beschichtung mit Proteinen der extrazellulären Matrix, wie z.B. Kollagen, oder mit aus diesen Makromolekülen abgeleiteten Adhäsionssequenzen positiv auf zelluläre Prozesse wie Adhäsion, Proliferation und Differenzierung ausgewirkt. Die positiven Wirkungen von Kollagen sind in vivo aufgrund eines raschen Abbaus durch proteolytische Enzyme nur zeitlich begrenzt vorhanden. Aus diesem Grund wurde in der vorliegenden Studie Kollagen kovalent an Titan gebunden und quervernetzt, und dessen Einfluß auf die Adhäsion und Proliferation von humanen Osteoblasten untersucht. Zur Immobilisierung der Kollagenschicht an die Metalloberfläche wurden verschiedene Silanhaft- vermittler und Quervernetzungsreagenzien getestet. Die Kombination eines Haftvermittlers mit primären Aminogruppen und eines wasserlöslichen Carbodiimids stellte sich dabei als das effektivste System zur Fixierung des fibrillären Kollagens heraus. Das Carbodiimid war dabei sowohl für die Quervernetzung der Kollagenmoleküle als auch für deren Anbindung an die Gruppen der silanisierten Titanoberfläche verantwortlich. Wir konnten feststellen, dass sich die kovalent gebundenen und quervernetzten Kollagenschichten als deutlich resistenter gegen einen enzymatischen Abbau in vitro erwiesen als physikalisch adsorbierte und quervernetzte Kollagenschichten. Die Adhäsion und Proliferation von humanen Osteoblasten (MG-63) war auf den Titanoberflächen am höchsten, die mit dem kovalent gebundenen fibrillären Kollagen modifiziert waren.

\section{Introduction}

A major goal in the design of biomaterials is to improve their surface properties in order to reduce immunological reactions and to enhance implant-tissue integration. For metallic materials which are commonly used for joint replacement, seve-

Institute of Physical and Theoretical Chemistry, University of Regensburg, Universitätsstrasse 31, 93053 Regensburg, Germany

${ }^{2}$ Department of Trauma Surgery, Center for Medical Biotechnology, Regensburg University Medical Center, Franz-Josef-Strauss-Allee 11, 93053 Regensburg, Germany ral techniques have been employed to improve the contact to bone. Besides physicochemical and morphological modifying procedures which generate surfaces of defined wettability or topography [1,2], the creation of biomimetic surfaces has emerged as promising strategy to improve cell adhesion and tissue integration of biomaterials [3]. Bioinspired surface modification of titanium implants has been realized by deposition of hydroxyapatite which is the major inorganic constituent of bone [4] or by immobilization of bioadhesive motifs derived from com- 
ponents of the extracellular matrix [5,6]. Precoating of implant materials with extracellular matrix proteins promoted cell adhesion [7] and osteogenic differentiation [8]. These proteins contain several sequences which function as ligands for various integrin and non-integrin receptors located at the cell membrane [9]. Binding to these receptors does not only enhance cell adhesion but also triggers signal transduction cascades which strongly influence cell spreading, migration, cell cycle progression, differentiation and cell survival [10,11].

Collagen type-I has been established as one promising candidate for bioactive surface engineering of titanium implants which accelerates receptor-mediated cell adhesion [12], osteoblast proliferation and differentiation in vitro [13,14], or periimplant bone growth in vivo [15]. In contrast to surface modification with low molecular weight molecules like adhesion motifs containing oligopeptides, collagen coating of metallic materials was mostly performed by adsorptive immobilization. But within the development of a bioactive coating for tantalized stainless steel implants, we could recently show that the stability of surface-bound collagen layers was significantly higher after covalent immobilization compared to adsorptive binding [16].

The aim of the present investigation was to enhance the cell adhesion properties of titanium substrates by covalent immobilization of reconstituted fibrillar type-I collagen. Different silane coupling agents and homo-bifunctional cross-linking molecules have been employed to achieve the best results regarding collagen binding capacity and enzymatic stability of the immobilized protein layers. The biological response to the titanium surface modification was investigated by in vitro cell adhesion and cell proliferation.

\section{Material and Methods \\ Activation of titanium surfaces}

Disk shaped specimens (15 mm diameter, $2 \mathrm{~mm}$ thick) of grade-2 commercially pure titanium (cp-Ti, Daido Steel Inc., USA) were prepared from rods by wire cutting (Viktor Hegedüs GmbH, Germany) and were polished on one side using polishing paste 113 GZW B1 (Menzerna GmbH \& Co KG, Germany). For comparative testing, $10 \mathrm{~mm} \times 10 \mathrm{~mm}$ squares of titanium coated silicon wafers (Infineon, Germany) were used with a titanium layer thickness of about $100 \mathrm{~nm}$. Surfaces were cleansed by immersing the specimens successively in acetone, toluene, acetone, ethanol, and water in an ultrasonic bath for $5 \mathrm{~min}$ each. Then the specimens were oxidized in $32.5 \%$ nitric acid solution with ultrasonic agitation for $10 \mathrm{~min}$, rinsed extensively with water, and temporarily dried in vacuum [17].

Silanization of the surfaces was performed by boiling the oxidized samples in solutions of $15 \mathrm{mg} / \mathrm{ml}$ of 3-aminopropyltriethoxysilane (APS) or 3-isocyanatopropyltriethoxysilane (IPS), which were obtained from ABCR GmbH \& Co. KG (Germany), in anhydrous toluene for $3 \mathrm{~h}[16,17]$. APS-coated samples were subsequently washed in chloroform, methanol, and water in an ultrasonic bath. IPS-coated surfaces were rinsed several times with dry toluene. Elemental composition of the modified surfaces were analyzed by X-ray photoelectron spectroscopy (XPS). Quantification of the surface-bound amino groups was performed by a colorimetric assay using sulfosuccinimidyl-40-(4,4'-dimethoxytrityl)-butyrate (sulfo-SDTB, Pierce, USA) according to the method described by Cook et al. [18].

APS-coated surfaces were activated by immersing the specimens in either a solution of $\mathrm{N}_{1} \mathrm{~N}^{\prime}$-disulphosuccinimidyl-suberate (DS3) in phosphate-buffered saline (PBS, $\mathrm{pH}=7.4$ ), or $\mathrm{N}, \mathrm{N}^{\prime}-$ disuccinimidyl-suberate (DSS) in N,N-dimethylformamide, or $1,1^{\prime}$-carbonyldimidazole (CDI), or N,N'-disuccinimidyl-carbo- nate (DSC) in acetonitrile, respectively. Each linker molecule was purchased from Sigma-Aldrich Chemie GmbH (Germany) and applied in a concentration of $0.1 \mathrm{~mol} / \mathrm{l}$ for $2 \mathrm{~h}$ at $20^{\circ} \mathrm{C}$. The samples were rinsed excessively with the solvent employed and then dried in vacuum. Surface-bound reactive groups were quantified colorimetrically by the use of the amino-functionalized dye 1-0-Dimethoxytrityl-3-amino-1-propanol (DAP) according to a protocol published previously [16].

\section{Stabilisation of collagen}

Fibrillar collagen was produced by in vitro-reconstitution of acid soluble type-I calf skin collagen (Fluka GmbH, Germany) according to a protocol of Geißler et al. [12]. One $\mathrm{ml}$ of a $1 \mathrm{mg} / \mathrm{ml}$ suspension of the reconstituted collagen in 2-morpholinoethanesulfonic acid-buffered solution (MES, $\mathrm{pH}=5.5$ ) was dried at $37^{\circ} \mathrm{C}$ in one well of 24-well plates (Nunc, Germany) to prepare collagen films. The films were re-hydrated by swelling them in water for $60 \mathrm{~min}$ before they were incubated in cross-linking solutions containing 1-ethyl-3-(3-dimethylaminopropyl)-carbodiimide (EDC) and N-hydroxysuccinimide (NHS), both of which were obtained from Fluka. The concentration of EDC in MES-buffered solution varied between 1 and $30 \mathrm{mg} / \mathrm{ml}$, and NHS was added in a EDC:NHS ratio of $4: 1$ (w/w). After cross-linking for $4 \mathrm{~h}$ at room temperature, the films were washed twice with $0.1 \mathrm{M} \mathrm{Na}_{2} \mathrm{HPO}_{4}$ for $1 \mathrm{~h}$ and 4 times with water for $30 \mathrm{~min}$ [19]. The degree of cross-linking was monitored via the amount of remaining free amino groups in the protein which was determined according to the protocol of Bubnis et al. [20] using trinitrobenzenesulfonic acid (TNBS). The shrinkage temperature (TS) of the collagen was determined by calorimetric measurements using a DSC-7 of Perkin Elmer Corporation (Norwalk, USA) as published previously [19].

\section{Immobilization of collagen}

For collagen coating of the titanium substrates, the differently modified metal specimens were superimposed with $1 \mathrm{ml}$ of the collagen suspension mentioned above for $4 \mathrm{~h}$ at $20^{\circ} \mathrm{C}$. After $1 \mathrm{~h}$ of incubation, a cross-linking solution was added to the collagen suspension resulting in a final concentration of 5.0 $\mathrm{mg} / \mathrm{ml} \mathrm{EDC} \mathrm{and} 1.25 \mathrm{mg} / \mathrm{ml}$ NHS. After collagen coating, the samples were rinsed gently with water and finally dried in a nitrogen stream. The amount of surface-bound collagen was determined by a modified picrosirius red-staining procedure $\mathrm{pu}-$ blished previously $[16,17]$.

\section{Stability testing of immobilized collagen}

For testing the enzymatic stability of immobilized and crosslinked collagen, $100 \mu \mathrm{l}$ of a $0.1 \mathrm{mg} / \mathrm{ml}$ collagen dispersion were spread homogeneously on the differently modified metal surfaces, dried in air, and cross-linked as described above. The collagen-coated specimens were incubated with a $1 \mathrm{mg} / \mathrm{ml} \mathrm{so-}$ lution of collagenase $\mathrm{P}$ from Clostridium histolyticum (EC3.4.24.3, Boehringer, Germany) in Dulbecco's modified Eagle's medium (DMEM, Gibco, Germany) for 1.5, 3, and $6 \mathrm{~h}$ at $37^{\circ} \mathrm{C}$. Thereafter, the residues of the collagen layers were rinsed with PBS and quantified with picrosirius red [16,17].

\section{Cell culture assay}

Human immortalized osteoblast-like cells MG-63 (ATCC CRL1427) were routinely cultivated in DMEM with high glucose content supplemented with 10\% fetal calf serum (FCS, PANBiotech GmbH, Germany) and penicillin-streptomycin (Gibco, USA) under standard conditions $\left(37^{\circ} \mathrm{C}, 5 \% \mathrm{CO}_{2}\right)$. Metal samples and collagen films were sterilized via beta irradiation with a dose of $25 \mathrm{kGy}$ by Beta-Gamma-Service GmbH (Germany), and osteoblasts were seeded in complete cell culture medium 


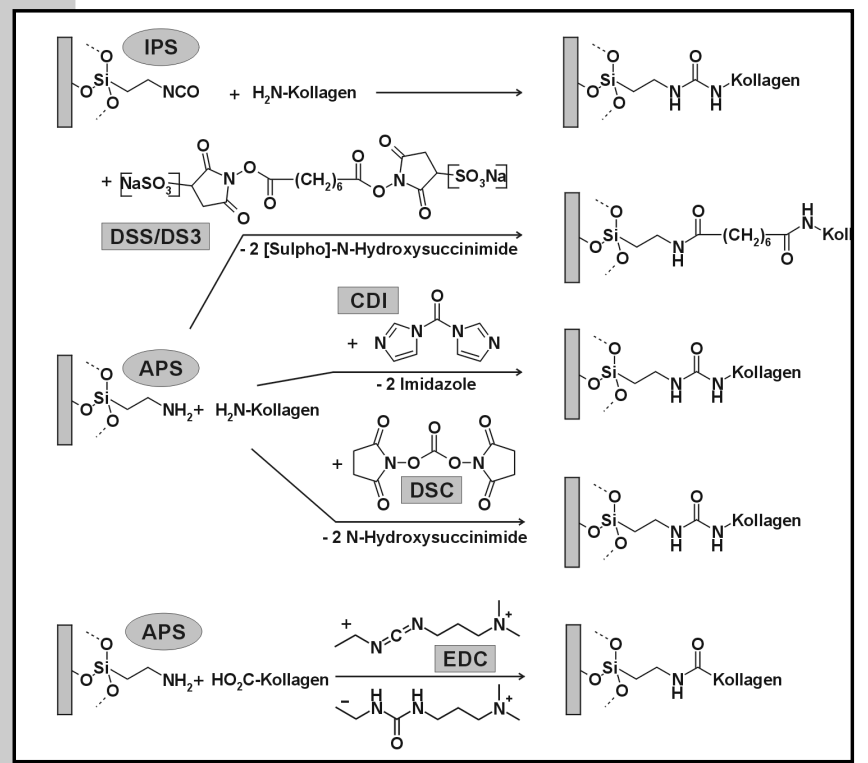

Figure I. Chemical pathways of covalent collagen immobilization examined in the present investigation. After coating the titanium substrate with isocyanatopropylsilane (IPS), collagen was bound to the reactive isocyanato groups without further activation. For coupling collagen to surface-immobilized aminopropylsilane molecules (APS), disuccinimidylsuberate (DSS), disulphosuccinimidylsuberate (DS3), carbonyldimidazole (CDI), disuccinimidylcarbonate (DSC), and ethyl-dimethylaminopropyl-carbodiimide (EDC) have been tested as cross-linking reagents.

onto specimens. For analysis of cell adhesion, 50,000 cells were cultivated on each substrate surface for 1 day, whereas 20,000 cells were cultivated for 7 days to determine cell proliferation. After removal of non-adherent cells by sucking-off the supernatant and rinsing with PBS, the number of attached cells was measured. The quantification of the cells was performed by their mitochondrial dehydrogenase activity using 3-(4,5-dimethylthiazol-2-yl)-5-(3-carboxymethoxyphenyl)-2(4-sulfophenyl)-2H-tetrazolium inner salt (MTS) and phenazine ethosulfate (PES) according to the protocol provided by the manufacturer (CellTiter96-Kit of Progema, Germany) [17].

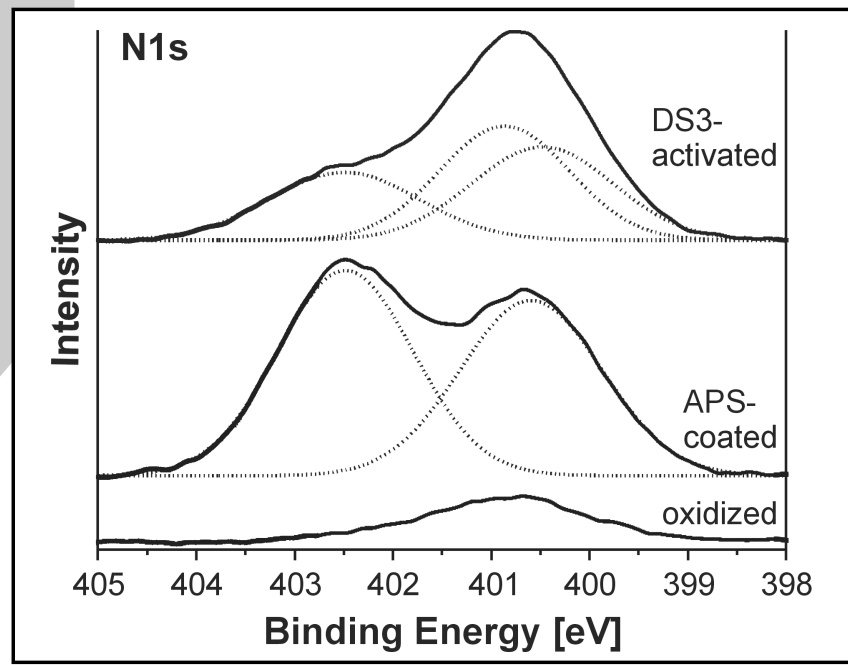

Figure 2. X-ray photoelectron spectroscopy (XPS) of titanium surfaces after nitric acid oxidation, coating with amino group-containing silane (APS), and activation of amino groups by homo-bifunctional cross-linker DS3. The regions of the N1s-signal indicating different binding states of the nitrogen atoms are displayed.
All results are shown as medians including the 25-75\% quantiles. The numbers (n) of the statistically independent samples are mentioned in the figure legends.

\section{Results and Discussion Silanization and activation of titanium surfaces}

Cp-titanium specimens were oxidized by nitric acid etching and coated with silane molecules containing either primary amino groups (APS) or isocyanato groups (IPS). While IPS-coating offers reactive functional groups for covalent immobilization of proteins, the amino groups of the APS-coating have to be activated to enable collagen immobilization. The activation of the surface-supported amino groups was performed using different linker molecules, thus introducing reactive chemical functions to the metal surface which are capable to bind collagen via its amino or carboxylic groups (Fig. 1).

Successful immobilization of APS molecules and their activation by the homo-bifunctional cross-linker DS3 was qualitatively demonstrated by the occurrence of nitrogen signals (N1s) in the XPS-spectra of the respective titanium surfaces (Fig. 2). APS-coating induced two new signals which could be assigned

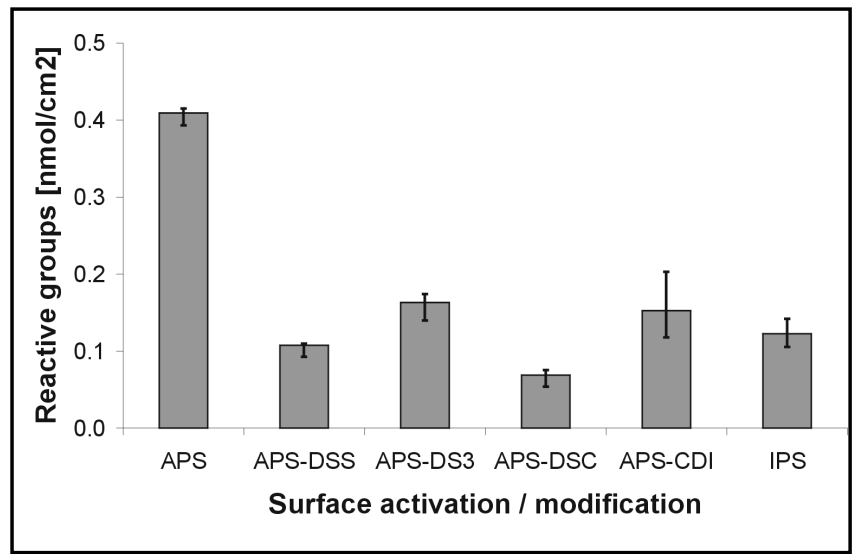

Figure 3. Quantification of surface-bound reactive functional groups after modification of titanium with silanes and activation with homo-bifunctional linker molecules. Surface-immobilized functional groups were detected using dimethoxytrityl-based dyes $(n=6)$.

to protonated $(402.5 \mathrm{eV})$ and non-protonated $(400.7 \mathrm{eV})$ primary amino groups. After application of DS3, the signal for the protonated primary amines was diminished and new signals were recorded representing amide $(400.4 \mathrm{eV})$ and imide $(400.9 \mathrm{eV})$ functions. Amides were formed by reaction of the activated carboxylic groups of the linker molecules with surface-bound amino groups and imide groups correspond to succinimidyl esters of the linker molecules that remained active to couple biomolecules via their amino groups.

Functional groups generated on the titanium surface after application of the different coating and activation procedures have been quantified by colorimetric assays using dimethoxytrityl-based dyes. As it is depicted in Fig. 3, APS-coating created the highest density of titanium-bound functional groups exhibiting an amino group concentration of about $0.4 \mathrm{nmol} / \mathrm{cm}^{2}$. The results obtained after application of the different linker molecules revealed that only fractional amounts of the surface-bound amino groups could be activated successfully. Here, the DS3 molecule was discovered as the most effective reagent by transforming approximately $40 \%$ of the amino groups into functions featuring protein-binding activity. Similar concentrations of surface-bound reactive groups 


\begin{tabular}{|l|l|l|l|}
\hline $\begin{array}{l}\text { EDC/NHS- } \\
\text { concentration }[\mathbf{m g} / \mathbf{m l}]\end{array}$ & $\begin{array}{l}\text { Free amino groups / } \\
\mathbf{1 0 0 0} \text { residues }\end{array}$ & $\begin{array}{l}\text { Shrinkage } \\
\text { temperature [ }{ }^{\circ} \mathbf{C} \text { ] }\end{array}$ & Cell adhesion [\%] \\
\hline $0.0 / 0.0$ & $32.6(30.7-34.8)$ & $49.6(49.4-49.6)$ & $100.0(94.3-102.7)$ \\
\hline $2.5 / 0.625$ & $25.7(24.5-27.5)$ & $58.0(57.6-58.2)$ & $131.3(\mid 24.3-132.5)$ \\
\hline $5.0 / 1.25$ & $11.0(10.3-11.1)$ & $63.9(63.7-65.3)$ & $125.0(\mid 14.3-135.1)$ \\
\hline $30.0 / 7.5$ & $3.0(2.9-3.1)$ & $74.4(73.9-75.2)$ & $116.6(101.8-127.4)$ \\
\hline
\end{tabular}

Table I: Characterization of reconstituted type-I calf skin collagen films depending on the concentration of the chemical cross-linking system EDC/NHS. Free amino groups of the collagen were determined by the TNBS assay and the results are presented as amino group content per amino acid residues ( $n=4)$. The shrinkage temperature of the collagen was evaluated by differential scanning calorimetry $(n=3)$. Adhesion of osteoblast-like cells was determined by the MTS-assay after 1 day of standard cell culture $(n=8)$. All results are shown as medians $(25-75 \%)$.

have been detected after coating the titanium surfaces with IPS molecules. All other procedures were found to be less effective and were excluded from further investigations.

\section{Stabilization of fibrillar collagen \\ by carbodiimide cross-linking}

Fibrillar collagen was produced by $\mathrm{pH}$ - and ionic strengthdriven reconstitution of water soluble collagen. Cross-linking of the reconstituted collagen was examined with respect to the concentration of the reagents EDC and NHS (Table 1). An increase in the concentration of the cross-linking reagents lead to a reduction of free amino groups which is an indicator for a rising cross-linking degree of the protein. Additionally, thermal stability of the collagen material, which has been examined by its shrinkage temperature, increased in the course of higher concentrations of the cross-linking reagents. Cytocompatibility of the modified collagen substrate was examined by a cell adhesion assay and was found to be influenced by the degree of chemical cross-linking. After application of low cross-linker concentrations (up to $5 \mathrm{mg} / \mathrm{ml} \mathrm{EDC),} \mathrm{cell} \mathrm{adhe-}$ sion was noticeably enhanced due to stabilization of the collagen substrate. In contrast, generation of a higher cross-linking degree resulted in reduced cell adhesion which is an indication of lower cytocompatibility of the chemically altered collagen substrate.

\section{Covalent immobilization of collagen on titanium}

Collagen was immobilized on titanium substrates exhibiting four different states of surface activation (Fig. 4). The incubation of oxidized but non-silanized surfaces resulted in an adsorptive binding of the cross-linked collagen layer. Employing this kind of immobilization, the lowest amount of surfacebound collagen was detected. Activation of the titanium surface with isocyanato groups (IPS) did not significantly enhance the amount of immobilized collagen compared to adsorptive binding. The relatively low surface density of functional groups and their high reactivity with water may be the reasons for the low efficacy of covalent binding using this method. If the metal surfaces exhibited amino groups (APS), the covalent attachment of collagen was achieved via its acidic residues, which got activated by the EDC/NHS cross-linking system. The high surface density of amino groups gives reason that this immobilization procedure resulted in the highest amount of titanium-bound collagen. However, prior activation of surface-attached amino groups by the homo-bifunc- tional cross-linker DS3 did not further enhance collagen immobilization. Again, the relatively low surface density of activated functional groups may be the reason for the worse performance of this coupling system.

As it is depicted in Fig. 5, the cross-linked collagen layer which was covalently bound to APS-modified titanium surfaces exhibited higher resistance against collagenase digestion compared to adsorptively bound cross-linked collagen. After an incubation period of $1.5 \mathrm{~h}$, already $83 \%$ of the physically adsorbed collagen was detached whereas only $32 \%$ of the covalently coupled collagen were digested. Within the following $4.5 \mathrm{~h}$ of collagenase incubation no further reduction of the collagen amount was detected.

\section{Cell culture on modified titanium surfaces}

The differences in adhesion and proliferation of MG-63 osteoblast-like cells after modification of titanium surfaces with either coupling reagents or differently bound collagen layers are displayed in Fig. 6 . The presence of surface-bound amino groups slightly enhanced cell adhesion compared to hydrophilic oxidized titanium but reduced 7-day cell proliferation.

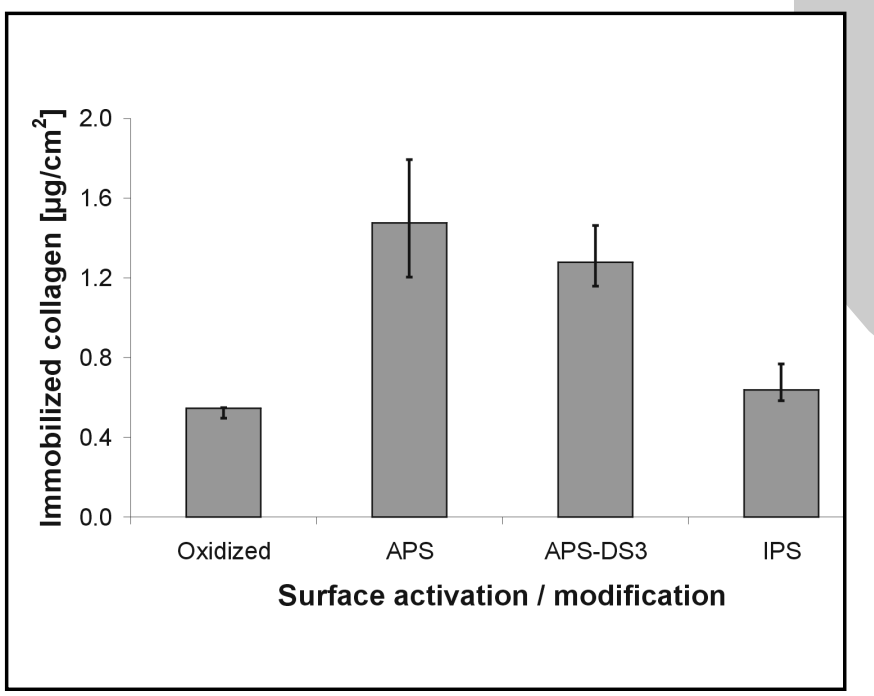

Figure 4. Collagen immobilization on differently modified titanium surfaces. All collagen layers were cross-linked by carbodiimide reaction (EDC/NHS) and quantified using the picrosirius red assay $(n=6)$. 
Similar results were obtained on surfaces exhibiting DS3-activated amino groups. It seems that the positively charged surfaces promote initial cell-biomaterial interactions but exhibit slightly cytotoxic effects during long term cell culture. Collagen layers which were physically adsorbed or covalently bound via the APS-DS3 system did not alter cell adhesion and proliferation in a noticeable manner. We hypothesize that the amount of immobilized collagen achieved by this two binding procedures was too low to positively affect osteoblast adhesion and proliferation. In contrast, cellular activity was nearly twice as high on APS-modified titanium surfaces on which the collagen layers were immobilized only by carbodiimide reaction. The high amount and high stability of the collagen layers resulting from this type of immobilization are mentioned as reasons for the improved cellular response. With the presented results we could show that covalent collagen immobilization is a promising strategy to enhance biocompatibility of biomaterials, especially of titanium implants.

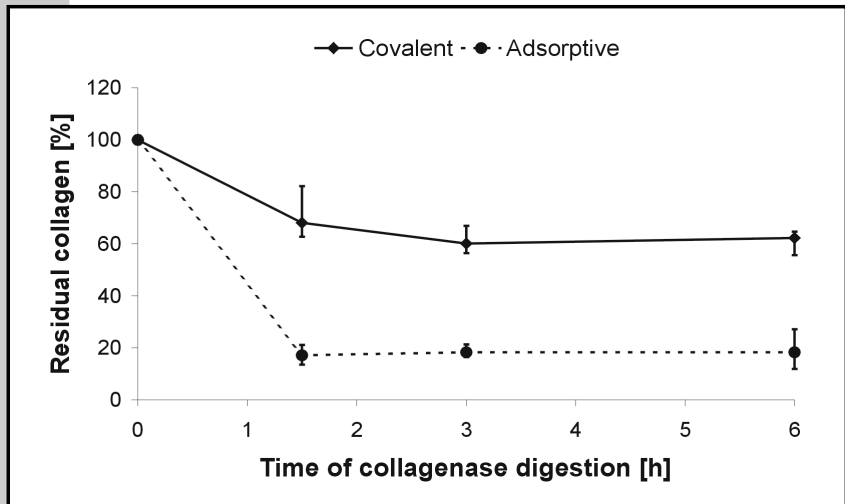

Figure 5. Stability of covalently and adsorptively bound collagen layers against collagenase digestion. Both collagen layers were cross-linked by carbodiimide reaction (EDC/NHS) whereby covalent attachment was realized on amino group (APS)-modified titanium surfaces and adsorptive binding on surfaces which were only oxidized. Residual collagen was quantified with picrosirius red $(n=4)$.

\section{Conclusion}

In the present study, we found that the EDC/NHS cross-linking system is able to covalently couple collagen molecules to amino group-modified titanium substrates. The concept of protein cross-linking by formation of amide-type bindings between carboxylic acids and amino groups is expandable to solid surfaces containing one sort of these chemical functions. This result is very beneficial, thus reducing the processing steps of covalent immobilization and reducing the potential risk of applying too many non-physiological molecules to the biomaterial surface.

\section{Acknowledgements}

We thank the Deutsche Forschungsgemeinschaft (DFG) for supporting the work within the program SPP 1100 (HE 378/29-2, NE 734/2-2). Special thanks to Martina Kreuzer, Ulrike Renner and Andrea Havazi for their excellent technical assistance and to Johann Vancea for performing the XPS-measurements.

\section{Abstract}

Initial cell adhesion is a major requirement for the integration of any implant material in the human body. Because it has

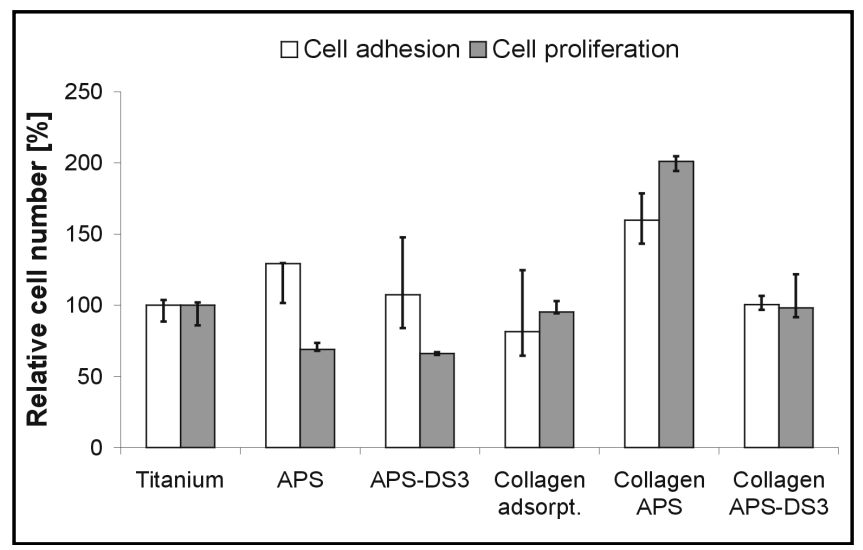

Figure 6. Adhesion (1 day) and proliferation (7 days) of MG-63 osteoblastlike cells on differently modified titanium surfaces. All collagen layers were cross-linked by carbodiimide reaction (EDC/NHS). Cell numbers were determined by the MTS-assay $(n=6)$.

been established that collagen accelerates receptor-mediated cell adhesion, the aim of the present study was to investigate the influence of titanium modification by covalent attachment of fibrillar collagen on adhesion and proliferation of osteoblastlike cells. Several silane coupling agents and cross-linking molecules have been tested to connect metal and protein, and to stabilize the bound collagen layer against biodegradation. We found that immobilization of collagen was most effective utilizing an amino group-containing silane and a water soluble carbodiimide, the latter performing both covalent attachment and protein cross-linking. In vitro-collagenase digestion revealed higher stability of the covalently bound and cross-linked collagen layer compared to a physically adsorbed and cross-linked collagen layer. Adhesion and proliferation of human osteoblast-like cells (MG-63) was enhanced on titanium biomaterials that have been modified with covalently immobilized and cross-linked fibrillar collagen.

\section{References}

[1] Hallab N. J., Bundy K.J., 0'Connor K., Moses R. L., Jacobs J. J.: Evaluation of metallic and polymeric biomaterial surface energy and surface roughness characteristics for directed cell adhesion. Tissue Engineering 7: 55-71, 2001 [2] Rupp F., Scheideler L., Olshanska N., De Wild M., Wieland M., Geis-Gerstorfer J.: Enhancing surface free energy and hydrophilicity through chemical modification of microstructured titanium implant surfaces. J Biomed Mater Res 76A: 323334, 2006

[3] Puleo D. A., Nanci A.: Understanding and controlling the bone-implant interface. Biomaterials 20: 2311-2321, 1999

[4] Weng W., Baptista J. L.: Preparation and characterization of hydroxyapatite coatings on Ti6Al4V alloy by a sol-gel method. J Am Ceram Soc 82: 27-32, 1999

[5] Xiao S. J., Textor M., Spencer N. D., Sigrist H.: Covalent Attachment of Cell-Adhesive, (Arg-Gly-Asp)-Containing Peptides to Titanium Surfaces. Langmuir 14: 5507-5516, 1998

[6] Rammelt S., Illert T., Bierbaum S., Scharnweber D., Zwipp H., Schneiders W.: Coating of titanium implants with collagen, RGD peptide and chondroitin sulfate. Biomaterials 27: 5561-5571, 2006

[7] Park J. C., Kim H. M., Ko J. S.: Effects of the extracellular matrix constituents on the attachment of human oral epithelial cells at the titanium surface. Int J Oral Maxillofac Implants 13: 826-836, 1998 


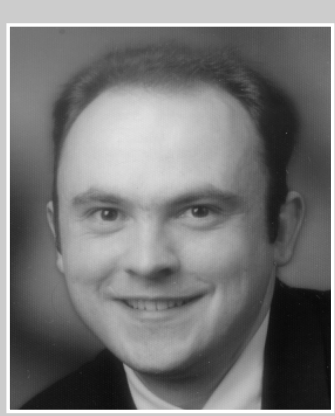

\section{Dr. rer. nat. Rainer Müller}

\section{Korrespondenzadresse:}

Universität Regensburg Institut für Physikalische und Theoretische Chemie Universitätsstrasse 31 93053 Regensburg E-Mail: rainer.mueller@ chemie.uni-regensburg.de

\section{Akademischer Lebenslauf}

Seit 2001 Wissenschaftlicher Assistent am Institut für Physikalische und Theoretische Chemie der Universität Regensburg (Prof. W. Kunz) und Habilitation auf dem Gebiet der physikalischen Chemie biologischer Grenzflächen.

1998-2000 Wissenschaftlicher Angestellter im Labor für Grenzflächenchemie der Universität Regensburg (Prof. K. Heckmann).

1995-1998 Promotion im Labor für Grenzflächenchemie der Universität Regensburg (Prof. K. Heckmann) mit dem Thema „Entwicklung von korrosionsinhibierenden Haftvermittlermolekülen für die Mikroelektronik“.

1994-1995 Diplomarbeit am Institut für Physikalische und Makromolekulare Chemie der Universität Regensburg (Prof. K. Heckmann) mit dem Thema „Synthese und physikalisch-chemische Analyse von biologisch abbaubaren kationischen Polyelektrolyten“.

1989-1993 Chemiestudium an der Universität Regensburg.

[8] Salasznyk R. M., Williams W. A., Boskey A., Batorsky A., Plopper G. E.: Adhesion to vitronectin and collagen I promotes osteogenic differentiation of human mesenchymal stem cells. J Biomed Biotech 1: 24-34, 2004

[9] Yamada K. M.: Adhesive recognition sequences. J Biol Chem 266: 12809-12812, 1991

[10] Ruoslahti E., Pierschbacher M. D.: New perspectives in cell adhesion: RGD and integrins. Science 238: 491-497, 1987 [11] Van der Flier A., Sonnenberg A.: Function and interactions of integrins. Cell Tissue Res 305: 285-298, 2001

[12] Geißler U., Hempel U., Wolf C., Scharnweber D., Worch H., Wenzel K. W.: Collagen Type I-coating of Ti6Al4V promotes adhesion of osteoblasts. J Biomed Mater Res 51:752-760, 2000 [13] Roehlecke C., Witt M., Kasper M., Schulze E., Wolf C., Hofer A., Funk R. H. W.: Synergistic effect of titanium alloy and collagen type I on cell adhesion, proliferation and differentiation of osteoblast-like cells. Cells Tissues Organs 168: 178-187, 2001

[14] Becker D., Geißler U., Hempel U., Bierbaum S., Scharnweber D., Worch H., Wenzel K.W.: Proliferation and differentiation of rat calvarial osteoblasts on type I collagen-coated titanium alloy. J Biomed Mater Res 59: 516-527, 2002

[15] Rammelt S., Schulze E., Bernhardt R., Hanisch U., Scharnweber D., Worch H., Zwipp H., Biewener A.: Coating of titanium implants with type-I collagen. J Orthop Res 22: 10251034, 2004

[16] Müller R., Abke J., Schnell E., Macionczyk F., Gbureck U., Mehrl R., Ruszczak Z., Kujat R., Englert C., Nerlich M., An- gele P.: Surface engineering of stainless steel materials by covalent collagen immobilization to improve implant biocompatibility. Biomaterials 26: 6962-6972, 2005

[17] Müller R., Abke J., Schnell E., Scharnweber D., Kujat R., Englert C., Taheri D., Nerlich M., Angele P.: Influence of surface pretreatment of titanium- and cobalt-based biomaterials on covalent immobilization of fibrillar collagen, Biomaterials 27:4059-4068, 2006

[18] Cook A. D., Pajvani U. B., Hrkach J. S., Canninzzaro S. M., Langer R.: Colorimetric analysis of surface reactive amino groups on poly(lactic acid-co-lysine) : poly(lactic acid) blends. Biomaterials 18:1417-1424, 1997

[19] Angele P., Abke J., Kujat R., Faltermeier H., Schumann D., Nerlich M., Kinner B., Englert C., Ruszczak Z., Mehrl R., Müller R.: Influence of different collagen species on physicochemical properties of crosslinked collagen matrices. Biomaterials 25: 2831-2841, 2004

[20] Bubnis W. A., Ofner III C. M.: The determination of $\hat{\mathrm{A}}$-amino groups in soluble and poorly soluble proteinaceous materials by a spectrophotometric method using trinitrobenzenesulfonic acid. Anal Biochem 207:129-133, 1992 